http://dx.doi.org/10.18778/1509-877X.2018.04.03

\title{
CZY SĄD ADMINISTRACYJNY MOŻE ODSTĄPIĆ OD KONTROLI NADUŻYCIA PRAWA POPEŁNIONEGO PRZEZ ORGANY SKARBOWE? UWAGI NA TLE WYROKU NACZELNEgo SĄDU AdMINISTRACYJNEgo Z DNIA 24 LISTOPADA 2016 R. (SYGN. I FSK 759/15)
}

Streszczenie. Autorka artykułu wskazuje na błędną praktykę sądów administracyjnych, zgodnie z którą nie badają one wszczęcia postępowania karnego skarbowego przez organy skarbowe w celu jedynie zawieszenia biegu terminu przedawnienia na podstawie art. $70 \$ 6$ pkt 1 ustawy - Ordynacja podatkowa (nadużycie prawa). Takie działanie jest niezgodne z konstytucyjnym i unijnym prawem do sądu, a także z zasadą państwa prawa i wywodzonych z nich zasad: legalności, praworządności, pewności prawa oraz prawa do dobrej administracji. W konsekwencji rezygnacja $\mathrm{z}$ takiej kontroli sądowej doprowadza do naruszenia prawa własności podatnika.

Słowa kluczowe: zawieszenie przedawnienia zobowiązania podatkowego, postępowanie karne skarbowe, prawo do sądu

\section{WPROWADZENIE}

Przyczynkiem do postawionego w tytule niniejszego artykułu pytania jest pogląd zawarty m.in. w wyroku Naczelnego Sądu Administracyjnego (NSA) z dnia 24 listopada 2016 r., sygn. I FSK 759/15, zgodnie z którym

* Doktor nauk prawnych, Uniwersytet Paris I Panthéon-Sorbonne w Paryżu, sędzia Wojewódzkiego Sądu Administracyjnego we Wrocławiu, e-mail: dagmara.dominik@wp.pl

1 CBOSA. 
unormowanie art. $70 \$ 6$ pkt 1 ustawy - Ordynacja podatkowa ${ }^{2}$ nie daje podstaw prawnych do weryfikacji wszczęcia postępowania karnego skarbowego. Wspomniane stanowisko zostało wyrażone na gruncie sprawy VAT w sytuacji, gdy zdaniem skarżącej strony, organ podatkowy dokonał wszczęcia postępowania karnego skarbowego dla pozoru, jedynie w celu zawieszenia biegu terminu przedawnienia.

Pogląd ten został przywołany również w uchwale składu 7 sędziów NSA z dnia 18 czerwca 2019 r., sygn. I FPS 1/1833. Odniesienie się do tego zagadnienia znajdowało się jednak poza zakresem postępowania uchwałowego, które ograniczone było treścią przedstawionego do rozstrzygnięcia zagadnienia prawnego ${ }^{4}$.

Warto też dodać, że kwestia nadużywania wspomnianego przepisu Ordynacji podatkowej była już nie raz sygnalizowana w literaturze ${ }^{5}$, a także przez Rzecznika Praw Obywatelskich ${ }^{6}$.

2 Ustawa z dnia 29 sierpnia 1997 r. - Ordynacja podatkowa (tekst jedn. Dz.U. z 2019 r., poz. 900, dalej: o.p.); art. $70 \$ 6$ pkt 1 o.p. stanowi, że bieg terminu przedawnienia zobowiązania podatkowego nie rozpoczyna się, a rozpoczęty ulega zawieszeniu, $z$ dniem: wszczęcia postępowania w sprawie o przestępstwo skarbowe lub wykroczenie skarbowe, o którym podatnik został zawiadomiony, jeżeli podejrzenie popełnienia przestępstwa lub wykroczenia wiąże się z niewykonaniem tego zobowiązania.

3 CBOSA.

4 Por. pkt 13 uchwały składu 7 sędziów NSA z dnia 18 czerwca 2019 r., sygn. I FPS 1/18 - pytanie Sądu odsyłającego zadane w postanowieniu z dnia 8 marca 2018 r., sygn. I FSK 657/16, było następujące: „Czy zawiadomienie podatnika dokonane na podstawie art. 70c [o.p.] [...] informujące, że z określonym co do daty dniem, «na skutek przesłanki z art. 70 $\$ 6$ pkt 1 o.p.» nastąpiło zawieszenie biegu terminu przedawnienia zobowiązania podatkowego podatnika za wskazany okres rozliczeniowy, jest wystarczające do stwierdzenia, że nastąpiło zawieszenie biegu terminu przedawnienia tego zobowiązania na podstawie art. $70 \leqq 6$ pkt 1 o.p.?”.

${ }^{5}$ O. Nieczepa, Poinformowanie podatnika o wszczęciu postępowania karnoskarbowego jako moment skutecznego zawieszenia biegu terminu przedawnienia zobowiązania podatkowego po uptywie 5-letniego terminu przedawnienia. Glosa do wyroku NSA z dnia 16 stycznia 2013 r., I FSK 1208/11, „Glosa” 2015, nr 3, s. 125-126; H. Gajewska-Kraczkowska, O prawdziwej funkcji zawieszenia postępowania karnego skarbowego, „Monitor Podatkowy” 2012, nr 4, s. 14; G. Łabuda, Zawieszenie postępowania karnego skarbowego ze względu na prejudykat, „Prokuratura i Prawo” 2011, nr 3, s. 78.

6 Por. pkt 13 uchwały składu 7 sędziów NSA z dnia 18 czerwca 2019 r., sygn. I FPS 1/18, a także wniosek Rzecznika Praw Obywatelskich do Trybunału Konstytucyjnego z dnia 22 października 2014 r., https://www.rpo.gov.pl/sites/default/files/Wniosek\%20do\%20TK \%20ws\%20ustaw\%20o\%20TK\%2027.01.2017.pdf. 
Spróbujmy zatem rozważyć wspomniany problem, patrząc przede wszystkim przez pryzmat roli sądu administracyjnego oraz istniejących standardów: konstytucyjnego, unijnego i międzynarodowego ${ }^{7} \mathrm{w}$ zakresie prawa do sądu.

\section{ROLA SĄDU ADMINISTRACYJNEGO I PRAWO DO SĄDU}

Rolą sądów (także sądów administracyjnych) jest wymierzanie sprawiedliwości, przez co należy rozumieć konkretyzowanie i realizowanie norm prawnych mających na celu ochronę zasad prawa. Wykonując to zadanie, sądy mają obowiązek orzekać sprawiedliwie. Kategoria sprawiedliwości jest immanentnie związana z procesem stosowania prawa i nie jest jedynie filozoficzną ideą. Konstytucja Rzeczypospolitej Polskiej z dnia 2 kwietnia $1997 \mathrm{r}^{8}$ nadała jej postać normatywną ${ }^{9}$ Stosownie do treści art. 175 ust. 1 Konstytucji RP wymiar sprawiedliwości w Rzeczypospolitej Polskiej sprawują Sąd Najwyższy, sądy powszechne, sądy administracyjne oraz sądy wojskowe. Sądy powszechne sprawują wymiar sprawiedliwości we wszystkich sprawach, $\mathrm{z}$ wyjątkiem spraw ustawowo zastrzeżonych dla właściwości innych sądów (art. 177 Konstytucji RP). W myśl art. 184 Konstytucji RP Naczelny Sąd Administracyjny oraz inne sądy administracyjne sprawują, w zakresie określonym w ustawie, kontrolę działalności administracji publicznej.

Istotą sądowej kontroli administracji jest ochrona wolności i praw jednostki (podmiotów prawa) w stosunkach $\mathrm{z}$ administracją publiczną oraz budowanie i utrwalanie zasady państwa prawa. Podstawową funkcją sądownictwa administracyjnego jest ochrona praw podmiotowych jednostki. Wypływa ona z założeń przyjętego systemu weryfikacji administracji publicznej w państwie prawa, co ma ścisły związek z realizacją zasady praworządności ${ }^{10}$. Podstawową formą, w jakiej sądy administracyjne sprawują kontrolę działalności administracji publicznej, jest wymierzanie sprawiedliwości przez wiążące rozstrzyganie sporów o prawo, w których przynajmniej jedną ze stron jest jednostka lub podmiot podobny. Tym samym

7 W przypadku tego ostatniego w ograniczonym zakresie, por. przypis 27.

8 Dz.U. z 1997 r., Nr 78, poz. 483 ze zm., dalej: Konstytucja RP.

9 Pozycja ustrojowa sędziego, red. R. Piotrowski, LEX/el. 2015.

${ }^{10}$ Por. J. Trzciński, Sąownictwo administracyjne jako gwarant ochrony wolności i praw jednostki, [w:] Trzecia władza. Sady i trybunały w Polsce, red. A. Szmyt, Gdańsk 2008, s. 128-129. 
treść i zakres działalności sądów administracyjnych muszą być ukształtowane $\mathrm{w}$ sposób zapewniający prawidłowe wymierzanie sprawiedliwości, czyli także prawo do sądu.

W tej perspektywie art. 184 Konstytucji RP dookreśla proceduralne aspekty prawa do sądu, można więc mówić o funkcji gwarancyjnej tego przepisu $^{11}$. Dookreślenie przez art. 184 Konstytucji RP proceduralnych aspektów prawa do sądu przejawia się przede wszystkim we wskazaniu, że sprawy, w których spór o prawo pojawia się na tle poddania jednostki władztwu administracji publicznej (sprawy administracyjne), powinny zostać zaliczone do właściwości sądownictwa administracyjnego ${ }^{12}$. Ustawy określające zakres kontroli sądu administracyjnego mają charakter dopełniający treść art. 184 zd. 1 Konstytucji RP w ten sposób, aby zapewnić realizację prawa do sądu przez kognicję sądu administracyjnego ${ }^{13}$. Zgodnie z art. $1 \$ 1$ Ustawy z dnia 25 lipca 2002 r. Prawo o ustroju sądów administracyjnych ${ }^{14}$ sądy administracyjne sprawują wymiar sprawiedliwości przez kontrolę działalności administracji publicznej oraz rozstrzyganie sporów kompetencyjnych i o właściwość między organami jednostek samorządu terytorialnego, samorządowymi kolegiami odwoławczymi oraz między tymi organami a organami administracji rządowej. Kontrola, o której mowa w $\$ 1$, sprawowana jest pod względem zgodności z prawem, jeżeli ustawy nie stanowią inaczej (art. $1 \$ 2$ Prawa o ustroju sądów administracyjnych). Z kolei zgodnie z art. $3 \$ 1$ ustawy Prawo o postępowaniu przed sądami administracyjnymi ${ }^{15}$ sądy administracyjne sprawują kontrolę działalności administracji publicznej i stosują środki określone w ustawie.

Kontrola sądów administracyjnych polega więc na zbadaniu, czy organ administracji publicznej nie naruszył prawa w stopniu mogącym mieć wpływ na wynik sprawy. Kontrola ta powinna zawsze przebiegać w trzech płaszczyznach: 1) oceny zgodności rozstrzygnięcia (decyzji albo innego

${ }^{11}$ L. Garlicki, Polskie prawo konstytucyjne. Zarys wykładu, Warszawa 2012, s. 332.

12 Konstytucja Rzeczypospolitej Polskiej. Komentarz, red. M. Haczkowska, LEX/el. 2014.

13 Wyrok Trybunału Konstytucyjnego (TK) z dnia 14 czerwca 1999 r., sygn. K. 11/98, LexisNexis nr 343593, OTK 1999, nr 5, poz. 97; podobnie m.in. wyrok TK z 15 grudnia 1999 r., sygn. P. 6/99, LexisNexis nr 344514, OTK 1999, nr 7, poz. 164; uchwała NSA z dnia 15 maja 2000 r., sygn. OPS 21/99, LexisNexis nr 348089, ONSA 2000, nr 4, poz. 135.

14 Tekst jedn. Dz.U. z 2018 r., poz. 2107 ze zm.

15 Ustawa z dnia 30 sierpnia 2002 r. Prawo o postępowaniu przed sądami administracyjnymi (tekst jedn. Dz.U. z 2017 r., poz. 1369 ze zm.). 
aktu) lub działania z prawem materialnym; 2) dochowania wymaganej prawem procedury; 3) respektowania reguł kompetencji ${ }^{16}$.

„Sprawowanie kontroli” oznacza pewnego rodzaju wtórność działań sądu wobec działań organów administracji. Rola sądu administracyjnego sprowadza się bowiem do badania (korygowania) działania lub zaniechania organów administracji publicznej, a nie zastępowania ich w załatwianiu spraw przez wydawanie końcowego rozstrzygnięcia w sprawie ${ }^{17}$.

Nie można zapominać, że w sprawach mających walor unijny (a za takie niewątpliwie należy uznać sprawy z zakresu VAT) sąd administracyjny jest sądem unijnym. Organy podatkowe nie są również zwolnione z obowiązku dokonywania wykładni zgodnej z prawem unijnym, które stanowi element polskiego porządku prawnego ${ }^{18}$. W myśl orzecznictwa Trybunału Sprawiedliwości Unii Europejskiej (TSUE) sądy krajowe są zobowiązane interpretować, w miarę możliwości, prawo krajowe w sposób zgodny z prawem Unii. Taka „wykładnia zgodna” może być, co do zasady, powoływana wobec podatnika przez właściwy krajowy organ podatkowy ${ }^{19}$. Do sądów krajowych i TSUE należy zapewnienie pełnego stosowania prawa Unii we wszystkich państwach członkowskich, a także ochrony sądowej praw, jakie podmioty prawa wywodzą z prawa $\mathrm{Unii}^{20}$.

3. PraWo do SĄDU

Przepis art. 175 Konstytucji RP należy rozpatrywać w ścisłym związku z postanowieniami art. 45 i art. 77 ust. 2 Konstytucji RP, gwarantującymi każdemu prawo do sądu, oraz z międzynarodowymi i unijnymi standardami wiążącymi Polskę - art. 14 ust. 1 Międzynarodowego Paktu Praw Obywatelskich i Politycznych ${ }^{21}$, art. 6 ust. 1 Konwencji o Ochronie Praw Człowieka

${ }^{16}$ B. Dauter, A. Kabat, M. Niezgódka-Medek, Prawo o postępowaniu przed sądami administracyjnymi. Komentarz, wyd. 7, LEX/el. 2018.

17 Konstytucja Rzeczypospolitej Polskiej. Komentarz, red. M. Haczkowska.

18 Artykuł 87 ust. 1, art. 91 ust. 1 i 3 Konstytucji RP.

19 Zob. podobnie wyroki TSUE z dnia: 26 września 1996 r., Arcaro, C-168/95, EU:C:1996:363, pkt 41, 42; 5 lipca 2007 r., Kofoed, C-321/05, EU:C:2007:408, pkt 45; 15 września 2011 r., Franz Mücksch, C-53/10, EU:C:2011:585, pkt 34; 8 maja 2019 r., Zwiqzek Gmin Zagłębia Miedziowego w Polkowicach, C-566/17, EU:C:2019:390, pkt 48.

${ }^{20}$ Wyrok TSUE z dnia 24 października 2018 r., XC, C-234/17, EU:C:2018:853, pkt 40.

${ }^{21}$ Konwencja otwarta do podpisu w Nowym Jorku dnia 16 grudnia 1966 r. (Dz.U. z 1977 r., Nr 38, poz. 167), dalej: Pakt. 
i Podstawowych Wolności ${ }^{22}$ oraz art. 47 Karty Praw Podstawowych Unii Europejskiej $^{23}$, które formułują prawo do sądu.

W myśl art. 45 ust. 1 Konstytucji RP każdy ma prawo do sprawiedliwego i jawnego rozpatrzenia sprawy bez nieuzasadnionej zwłoki przez właściwy, niezależny, bezstronny i niezawisły sąd (prawo do sądu). Artykuł 77 ust. 2 Konstytucji RP wskazuje, że ustawa nie może nikomu zamykać drogi sądowej dochodzenia naruszonych wolności lub praw. Rozpatrując „prawo do sądu” jako jedno z konstytucyjnych praw (i to praw „osobistych”), należy przyjąć, że oznacza ono możliwość zwrócenia się w każdej sytuacji (sprawie) do sądu z żądaniem określenia (ustalenia) statusu prawnego jednostki. Jak wielokrotnie wskazywał Trybunał Konstytucyjny, na treść prawa do sądu składają się: 1) prawo dostępu do sądu, tj. prawo uruchomienia procedury przed sądem - organem o określonej charakterystyce (niezależnym, bezstronnym i niezawisłym); 2) prawo do odpowiedniego ukształtowania procedury sądowej, zgodnie z wymogami sprawiedliwości i jawności; 3) prawo do wyroku sądowego, tj. prawo do uzyskania wiążącego rozstrzygnięcia danej sprawy przez sąd; 4) prawo do odpowiedniego ukształtowania ustroju i pozycji organów rozpoznających sprawy ${ }^{24}$. Prawo jednostki do sądu jest realizowane przez całokształt zasad prowadzących do rzetelnego i merytorycznie prawidłowego rozpoznania sprawy w rozsądnym czasie ${ }^{25}$.

„ «Rozpatrywanie» oznacza wszechstronne zapoznanie się ze wszystkimi aspektami sprawy [...]. Rozpatrzenie sprawiedliwe, naturalnie koreluje z ogólną funkcją sądów, jaką jest wymierzanie sprawiedliwości. Oba te określenia wymagają, aby rozpatrując sprawy i ferując orzeczenia, przy działaniu na podstawie przepisów prawa, niezależnie i niezawiśle - sądy kierowały się w ich stosowaniu i interpretacji społecznym poczuciem sprawiedliwości, wszelako pamiętając również o wychowawczym aspekcie funkcji sądowniczej i nie kierując się mechanicznie opinią publiczną"26.

22 Konwencja sporządzona w Rzymie dnia 4 listopada 1950 r., zmieniona następnie Protokołami nr 3, 5 i 8 oraz uzupełniona Protokołem nr 2 (Dz.U. z 1993 r., Nr 61, poz. 284), dalej: Europejska Konwencja.

${ }_{23}^{2}$ 2007/C 303/01 (Dz.Urz. UE z dnia 14 grudnia 2007 r., C 303, s. 1), dalej: Karta.

24 Zob. wyroki TK z dnia: 10 lipca 2000 r., sygn. SK 12/99, OTK ZU 2000, nr 5, poz. 143; 24 października 2007 r., sygn. SK 7/06, OTK ZU 2007, nr 9/A, poz. 108.

${ }_{25}$ Por. wyrok TK z dnia 18 lutego 2009 r., sygn. Kp 3/08, OTK ZU 2009, nr 2/A, poz. 9.

26 Por. Konstytucja Rzeczypospolitej Polskiej. Komentarz, t. 2, red. L. Garlicki, M. Zubik, wyd. 2, LEX/el. 2016. 
Zasadniczo prawo do sądu wyrażone w polskiej Konstytucji ma identyczną wręcz treść jak międzynarodowe akty prawne. Wynika to z faktu, że cechą charakterystyczną regulacji konstytucyjnej statusu jednostki w Polsce jest dążenie do odzwierciedlenia standardów międzynarodowych, a także do precyzyjnego i w miarę możliwości jednoznacznego określenia zakresu przysługujących wolności i praw ${ }^{27}$. Konstytucja dokonała zatem niemal dosłownej recepcji wspomnianych norm prawa międzynarodowego i stanowi też powtórzenie norm prawa unijnego.

I tak, zgodnie z art. 14 ust. 1 zd. 1 i 2 Paktu, wszyscy ludzie są równi przed sądami i trybunałami. Każdy ma prawo do sprawiedliwego i publicznego rozpatrzenia sprawy przez właściwy, niezależny i bezstronny sąd, ustanowiony przez ustawę, przy orzekaniu co do zasadności oskarżenia przeciw niemu w sprawach karnych bądź co do jego praw i obowiązków w sprawach cywilnych.

Artykuł 6 ust. 1 zd. 1 Europejskiej Konwencji wskazuje, że każdy ma prawo do sprawiedliwego i publicznego rozpatrzenia jego sprawy w rozsądnym terminie przez niezawisły i bezstronny sąd ustanowiony ustawą przy rozstrzyganiu o jego prawach i obowiązkach o charakterze cywilnym albo o zasadności każdego oskarżenia w wytoczonej przeciwko niemu sprawie karnej.

Stosownie zaś do art. 47 zd. 1 i 2 Karty każdy, czyje prawa i wolności zagwarantowane przez prawo Unii zostały naruszone, ma prawo do skutecznego środka prawnego przed sądem, zgodnie $\mathrm{z}$ warunkami przewidzianymi w tymże artykule. Każdy ma prawo do sprawiedliwego i jawnego rozpatrzenia jego sprawy w rozsądnym terminie przez niezawisły i bezstronny sąd ustanowiony uprzednio na mocy ustawy. Każdy ma możliwość uzyskania porady prawnej, skorzystania z pomocy obrońcy i przedstawiciela.

Pakt nie ma szerszego zastosowania w praktyce sądów administracyjnych ${ }^{28}$, albowiem sądy powołują się na ten akt jedynie w celu stworzenia pewnej podstawy aksjologicznej dla budowanej przez siebie argumentacji

${ }_{27}$ R. Wieruszewski, Oddziaływanie prawa międzynarodowego i prawa Unii Europejskiej na konstytucyjny status jednostki w RP, [w:] Otwarcie Konstytucji RP na prawo międzynarodowe i procesy integracyjne, Warszawa 2006, s. 189.

${ }_{28}$ Szerzej na ten temat A. Tychmańska, Znaczenie Międzynarodowego Paktu Praw Obywatelskich i Politycznych oraz Międzynarodowego Paktu Praw Gospodarczych, Społecznych i Kulturalnych dla polskiego porządku prawnego na przykładzie analizy orzecznictwa polskich sądów administracyjnych, „Studenckie Zeszyty Naukowe” 2017, t. 22, nr 34. 
- uzasadniając dane rozstrzygnięcie, z reguły najpierw przywołują normy wynikające $\mathrm{z}$ Paktu, zestawiając je z normami konstytucyjnymi chroniącymi dane prawa i wolności jednostek ${ }^{29}$.

Niewątpliwie jednak, zasadniczym punktem odniesienia dla ochrony praw człowieka w Europie jest Europejska Konwencja ${ }^{30}$, m.in. ze względu na jej znaczenie historyczne, bogate i nowatorskie orzecznictwo, rolę jej oraz orzecznictwa Europejskiego Trybunału Praw Człowieka (ETPC). Dla potrzeb niniejszego artykułu warto przypomnieć, że na gruncie art. 6 ust. 1 Europejskiej Konwencji wyłącznie instytucja posiadająca pełną jurysdykcję zasługuje na miano „sądu”31. Artykuł 6 ust. 1 Europejskiej Konwencji nakłada na sądy wymóg dokonania skutecznej sądowej oceny sprawy ${ }^{32}$. Zasada, że sąd powinien sprawować pełną jurysdykcję, pociąga za sobą wymóg nierezygnowania przez sądy z żadnego elementu składowego ich funkcji orzekającej ${ }^{33}$. Rozpatrujący sprawę „sąd” musi posiadać jurysdykcję do zbadania wszystkich kwestii faktycznych i prawnych mających istotne znaczenie dla przedstawionego mu do rozstrzygnięcia sporu ${ }^{34}$. ETPC dostrzegał naruszenia art. 6 ust. 1 Europejskiej Konwencji wtedy, gdy kontrolujący sąd nie mógł orzec w przedmiocie głównego przedmiotu sporu lub gdy sądy krajowe uznawały się za związane uprzednimi ustaleniami organów administracyjnych, mającymi decydujące znaczenie dla rozpatrywanych przez te organy spraw, nie badając tych zagadnień w sposób niezależny ${ }^{35}$. Warto jest wskazać, że w myśl art. 52 ust. 3 Karty w zakresie, w jakim Karta zawiera prawa, które odpowiadają prawom zagwarantowanym

${ }_{29}$ Por. np. wyroki NSA z dnia: 16 maja 2006 r., sygn. I OSK 8/06; 14 kwietnia 2016 r., sygn. I OSK 2493/14, CBOSA; w dalszej części rozważań pominięty zostanie ten standard, albowiem znajduje on odzwierciedlenie w Europejskiej Konwencji.

${ }^{30}$ G. Szyburska-Walczak, Oddziaływanie Europejskiej Konwencji o ochronie praw człowieka i podstawowych wolności na internacjonalizację standardów w dziedzinie demokracji i praw człowieka, [w:] Wpływ standardów międzynarodowych na rozwój demokracji i ochrone praw człowieka, red. J. Jaskiernia, Warszawa 2013, s. 13.

31 Wyrok ETPC z dnia 24 listopada 1994 r., Beaumartin przeciwko Francji, skarga nr 15287/89, § 38 .

32 Wyrok ETPC z dnia 28 czerwca 1990 r., Obermeier przeciwko Austrii, skarga nr $11761 / 85, \S 70$.

33 Wyrok ETPC z dnia 13 lutego 2003 r., Chevrol przeciwko Francji, skarga nr 49636/99, § 63.

34 Wyrok ETPC z dnia 17 grudnia 1996 r., Terra Woningen B.V. przeciwko Holandii, skarga nr 20641/92, \$ 52 .

35 Wyrok ETPC z dnia 28 maja 2002 r., Kingsley przeciwko Zjednoczonemu Królestwu, skarga nr 35605/97, \$32-34. 
w Europejskiej Konwencji o ochronie praw człowieka i podstawowych wolności, ich znaczenie i zakres są takie same jak prawa przyznane przez tę konwencję. Powyższe nie stanowi przeszkody, aby prawo Unii przyznawało szerszą ochronę. Europejska Konwencja wyznacza zatem minimalny standard ochrony ${ }^{36} \mathrm{w}$ sprawach $\mathrm{z}$ zakresu stosowania prawa Unii i pozostaje tym samym niewątpliwym źródłem inspiracji.

Ponadto po wejściu w życie Traktatu $\mathrm{z}$ Lizbony ${ }^{37}$ skuteczność ochrony sądowej uzyskała podwójną postać: skuteczność jako jeden z dwóch wymogów ${ }^{38} \mathrm{w}$ zakresie autonomii proceduralnej państw członkowskich oraz skuteczność związaną z prawem podstawowym do skutecznego środka prawnego przez sądem zgodnie z art. 47 Karty. Nie zapominajmy bowiem, że zgodnie z art. 6 ust. 1 Traktatu o Unii Europejskiej ${ }^{39}$ „Unia uznaje prawa, wolności i zasady określone w Karcie [...], która ma taką samą moc prawną jak Traktaty”. Jak zauważył Rzecznik Generalny M. Bobek w swojej opinii z dnia 10 kwietnia 2018 r. do sprawy C-89/17, pkt 101 i następne ${ }^{40}$, na podstawie orzecznictwa TSUE można dojść do wniosku, że art. 47 Karty wyznacza obecnie wyższy standard niż zasada skuteczności. W kontekście zasady skuteczności jako ograniczenia autonomii proceduralnej państw członkowskich Trybunał orzekł, że nie jest konieczne, by we wszystkich okolicznościach sądy mogły zastąpić decyzję własnym rozstrzygnięciem co do istoty sprawy i okoliczności faktycznych. Orzecznictwo Trybunału pokazuje także, że kontrola sądowa, która jest ograniczona w odniesieniu do oceny określonych kwestii faktycznych, nie zawsze powoduje, iż wykonywanie praw wynikających z porządku prawnego Unii staje się praktycznie niemożliwe lub nadmiernie utrudnione ${ }^{41}$. Istotne jest to, że krajowa

${ }^{36}$ Artykuł 53 Karty stanowi, że żadne z postanowień Karty nie będzie interpretowane jako ograniczające lub naruszające prawa człowieka i podstawowe wolności uznane, we właściwych im obszarach zastosowania, przez prawo Unii i prawo międzynarodowe oraz konwencje międzynarodowe, których Unia lub wszystkie Państwa Członkowskie są stronami, w szczególności przez europejską Konwencję o ochronie praw człowieka i podstawowych wolności oraz przez konstytucje Państw Członkowskich; por. wyrok TSUE z dnia 26 lutego 2013 r., Melloni, C-399/11, EU:C:2013:107.

37 Traktat obowiązuje od dnia 2 grudnia 2009 r. (Dz.U. z 2009 r., Nr 203, poz. 1569).

38 Drugim wymogiem jest równoważność środka, por. np. wyrok TSUE z dnia 28 lipca 2016 r., Astone, C-332/15, EU:C:2016:614, pkt 34.

39 Dz.U. z 2004 r., Nr 90, poz. 864/30, dalej: TUE.

40 EU:C:2018:225.

${ }^{41}$ Wyrok TSUE z dnia 6 października 2015 r., East Sussex County Council, C-71/14, EU:C:2015:656, pkt 58. 
procedura kontroli sądowej umożliwia sądowi krajowemu rozpatrującemu skargę - w ramach kontroli jej zgodności z prawem - stosowanie odpowiednich zasad i norm prawa Unii ${ }^{42}$. Zakres i natężenie kontroli sądowej wymagane przez zasadę skuteczności zależą od treści i charakteru właściwych zasad i przepisów prawa Unii implementowanych w zaskarżonej decyzji krajowej ${ }^{43}$. Obowiązek przeprowadzenia bardziej kompleksowej kontroli, uwzględniającej ocenę faktów i merytorycznej trafności decyzji, zyskuje na znaczeniu w świetle wymagań art. 47 Karty wtedy, gdy takie badanie jest istotne, biorąc pod uwagę okoliczności konkretnej sprawy.

Jeśli chodzi o prawo dostępu do sądu, Trybunał orzekł, że aby sąd mógł zgodnie $\mathrm{z}$ art. 47 Karty podjąć decyzję w sprawie sporu dotyczącego praw i obowiązków wynikających z prawa Unii, musi być uprawniony do zbadania wszystkich kwestii prawnych i faktycznych istotnych dla rozstrzyganego przez niego sporu ${ }^{44}$. Przestrzeganie prawa do skutecznej ochrony sądowej musi zatem zostać zbadane w odniesieniu do specyficznego kontekstu i istotnych okoliczności danej sprawy, w szczególności charakteru rozpatrywanego aktu, okoliczności jego przyjęcia oraz przepisów prawa regulującego daną dziedzinę $e^{45}$. W związku z tym, biorąc pod uwagę szczególne przepisy prawa Unii i specyficzną naturę przedmiotowych praw i interesów, Trybunał nalegał na potrzebę dogłębnej kontroli decyzji w odniesieniu zarówno do okoliczności faktycznych, jak i prawa, zwłaszcza wtedy, gdy rozpatrywany instrument obejmował już określone zharmonizowane standardy proceduralne ${ }^{46}$. Taki sposób rozumowania dotyczy, zgodnie z art. 51 ust. 1 Karty, spraw z zakresu stosowania prawa Unii.

42 Wyroki TSUE z dnia: 6 października 2017 r., East Sussex County Council, C-71/14, EU:C:2015:656, pkt 58; 21 stycznia 1999 r., Upjohn, C-120/97, EU:C:1999:14, pkt 30, 35, 36; 9 czerwca 2005 r., HLH Warenvertrieb i Orthica, C-211/03, C-299/03 i od C-316/03 do C-318/03, EU:C:2005:370, pkt 75-79.

${ }^{43}$ Wyroki TSUE z dnia: 11 grudnia 2014 r., Croce Amica One Italia, C-440/13, EU:C:2014:2435, pkt 40-45; 18 czerwca 2002 r., HI, C-92/00, EU:C:2002:379, pkt 59-64.

${ }^{44}$ Wyroki TSUE z dnia: 6 listopada 2012 r., Otis $i$ in., C-199/11, EU:C:2012:684, pkt 49; 17 grudnia 2015 r., Imtech Marine Belgium, C-300/14, EU:C:2015:825, pkt 38.

45 Wyroki TSUE z dnia: 18 lipca 2013 r., Komisja i in./Kadi, C-584/10 P, C-593/10 P i C-595/10 P, EU:C:2013:518, pkt 102; 9 lutego 2017 r., M., C-560/14, EU:C:2017:101, pkt 33; 26 lipca 2017 r., Sacko, C-348/16, EU:C:2017:591, pkt 41.

46 Wyrok TSUE z dnia 28 lipca 2011 r., Samba Diouf, C-69/10, EU:C:2011:524, pkt 56, 57, 61 . 
Uwzględniając powyższy standard konstytucyjny, należy stwierdzić, że poza kontrolą sądu administracyjnego nie można pozostawić kwestii zasadności zastosowania przez organy podatkowe art. $70 \$ 6$ pkt 1 o.p. (zawieszenie biegu terminu przedawnienia) w związku ze wszczęciem postępowania karnego skarbowego przez organ skarbowy, działający jako organ postępowania przygotowawczego $\mathrm{w}$ sprawach o przestępstwa skarbowe i wykroczenia skarbowe $\mathrm{w}$ rozumieniu art. $118 \$ 1$ pkt 2 Ustawy z dnia 10 września 1999 r. Kodeks karny skarbowy ${ }^{47}$. Ocena, czy w sprawie doszło do upływu terminu przedawnienia zobowiązania podatkowego, czy też do niego nie doszło, jest bowiem warunkiem wstępnym kontroli zaskarżonej decyzji, który wojewódzki sąd administracyjny zobowiązany jest brać pod uwagę z urzędu (przeciwnie do NSA, który przedawnienie bada na zarzut przedstawiony w skardze kasacyjnej ${ }^{48}$ ).

Na gruncie krajowym Trybunał Konstytucyjny akcentował wyjątkowy charakter zawieszenia biegu przedawnienia ze względu na to, że narusza ono poczucie bezpieczeństwa podatnika i nie sprzyja poszanowaniu jego godności ${ }^{49}$. Skoro zatem przypadek określony w art. $70 \$ 6$ pkt 1 o.p. stanowi wyjątek od ogólnej zasady przedawnienia zobowiązań podatkowych, to powinien być interpretowany w sposób ścisły i stosowany w zgodzie z gwarancyjną funkcją instytucji przedawnienia ${ }^{50}$. Celem tego przepisu jest dobro toczącego się postępowania podatkowego (oddaje on bowiem do dyspozycji organów podatkowych dodatkowy czas pozwalający na weryfikację prawidłowości dokonanego przez podatnika rozliczenia). Ze względu jednak właśnie na jego wymiar gwarancyjny, dobro toczącego się postępowania podatkowego musi zostać odpowiednio wyważone $\mathrm{z}$ dobrem podatnika, który chciałby

47 Tekst jedn. Dz.U. z 2016 r., poz. 2137 ze zm.

48 Por. art. $183 \$ 1 \mathrm{w}$ zw. $\mathrm{z}$ art. $176 \$ 1$ pkt 2 Ustawy z dnia 30 sierpnia $2002 \mathrm{r}$. Prawo o postępowaniu przed sądami administracyjnymi (tekst jedn. Dz.U. z 2018 r., poz. 1302 ze zm.).

${ }^{49}$ Wyroki TK z dnia: 19 czerwca 2012 r., sygn. P 41/10, OTK-A 2012/6/65; 17 lipca 2012 r., sygn. P 30/11, OTK-A 2012/7/81.

50 Por. wyroki NSA z dnia: 24 listopada 2016 r., sygn. II FSK 1488/15; z 19 kwietnia 2018 r., sygn. II FSK 923/16 i II FSK 889/16, CBOSA. 
mieć pewność co do swojej sytuacji prawnopodatkowej ${ }^{51}$. Z orzecznictwa ${ }^{52}$ wynika, że nie ma konstytucyjnego prawa podmiotowego do przedawnienia ani też ekspektatywy takiego prawa. Przedawnienie w prawie podatkowym należy rozpatrywać przede wszystkim w świetle art. 84 Konstytucji RP ustanawiającego powszechny obowiązek ponoszenia ciężarów i świadczeń publicznych oraz art. 217 Konstytucji RP statuującego władztwo finansowe państwa. Wprowadzenie przedawnienia w prawie podatkowym, a także określenie terminu, w jakim ono nastąpi, pozostawione jest uznaniu ustawodawcy. Ustawodawca może równocześnie wybierać między różnymi konstrukcjami przedawnienia, ustanawiając odrębne terminy przeprowadzenia czynności weryfikujących wywiązywanie się podatników z ich obowiązków oraz odrębne terminy egzekucji należności. Terminy te nie mogą jednak być zbyt krótkie, ponieważ wyłączałyby zapewnienie realizacji zasady powszechności i sprawiedliwości podatkowej, ani nie mogą pozostawać zbyt długie, czyniąc przedawnienie instytucją pozorną. Przedawnienie zobowiązania podatkowego, aby nie było instytucją pozorną, musi również realizować stawiane mu cele, tj. dawać podatnikowi poczucie pewności co do braku ciążących na nim zobowiązań podatkowych i działać w sposób dyscyplinujący na wierzyciela podatkowego. Długi termin przedawnienia, wyznaczający jednocześnie horyzont czasowy prowadzenia przez organy skarbowe postępowań dotyczących podatników, może rodzić trudności w rzetelnym ich przeprowadzeniu, stając się w rezultacie swoistą pułapką także na uczciwych podatników. Ustawodawca powinien ukształtować mechanizmy prawa podatkowego w taki sposób, by w rozsądnym terminie doprowadziły one do wygaśnięcia zobowiązania podatkowego. Dodatkowo zaznaczono, że szeroki margines swobody ustawodawcy w zakresie ukształtowania zasad przedawnienia nie jest absolutny. Ustawodawcę wiąże bowiem, z jednej strony, zasada państwa prawnego (w tym zakaz arbitralnego traktowania jednostek), z drugiej zaś - potrzeba ochrony wolności i praw obywateli. Jakkolwiek przedawnienie nie jest konstytucyjnym prawem podmiotowym jednostki, to jednak w ocenie Trybunału Konstytucyjnego ustanowienie przedawnienia wynika z zasady demokratycznego państwa prawa, o której mowa w art. 2 Konstytucji RP, stanowiąc przejaw zasady bezpieczeństwa prawnego. Jednym z przejawów bezpieczeństwa prawnego jest stabilizacja sytuacji prawnej jednostki, przekładająca

51 Por. wyrok TK z dnia 17 lipca 2012 r., sygn. P 30/11, OTK-A 2012/7/81.

${ }^{52}$ Por. wyroki TK z dnia: 21 czerwca 2011 r., sygn. P 26/10, OTK ZU nr 5/A/2011, poz. 43; 17 lipca 2012 r., sygn. P 30/11, OTK-A 2012/7/81; 18 lipca 2013 r., sygn. SK 18/09, OTK-A 2012/6/80. 
się w efekcie na stabilizację stosunków społecznych. Z art. 2 Konstytucji RP wynika tym samym obowiązek ustawodawcy ukształtowania regulacji prawnych, które będą sprzyjały wygaszaniu - wraz z upływem czasu - stanu niepewności. Z aksjologii konstytucyjnej opartej na fundamencie przyrodzonej oraz niezbywalnej godności człowieka (art. 30 Konstytucji RP) wynika obowiązek tworzenia prawa zorientowanego na dobro każdej osoby ludzkiej.

Zważywszy na powyższe, nie można podzielić wskazywanego na wstępie poglądu, że unormowanie art. $70 \$ 6$ pkt 1 o.p. nie daje podstaw prawnych do weryfikacji wszczęcia tego postępowania karnego skarbowego. Powyższa koncepcja w skutkach niejako z założenia oznacza rezygnację/odstąpienie przez sąd $z$ udzielonej mu kompetencji i nie wypełnia (a niewątpliwie może prowadzić do zakłócenia) standardu konstytucyjnego w przedmiocie prawa do skutecznego środka prawnego i dostępu do bezstronnego sądu (art. 45 ust. 1 Konstytucji RP). Stanowi rodzaj ograniczenia tego prawa, co pośrednio skutkuje naruszeniem efektywności prawa do własności określonego w art. 21 ust. 1 i art. 64 Konstytucji RP. Ustawodawca, włączając pewne konstrukcje karne skarbowe do Ordynacji podatkowej, decyduje o tym, że stają się one elementem instytucji prawa podatkowego. I jak każdy element tych instytucji, powinien podlegać badaniu sądu administracyjnego. Jeżeli sąd uchyla się od badania sposobu stosowania instytucji karnych skarbowych włączonych do prawa podatkowego, oznacza to, że rezygnuje ze zbadania kwestii prawnej mającej istotne znaczenie dla rozstrzygnięcia sporu.

Przy wskazywanym wyżej stanowisku każde wszczęcie postępowania karnego skarbowego, nawet w sytuacji braku jakichkolwiek podstaw materialnoprawnych czy procesowych, wywoływałoby skutek w zakresie zawieszenia biegu terminu przedawnienia zobowiązania podatkowego pozostający poza jakąkolwiek kontrolą sądu administracyjnego.

W demokratycznym państwie prawnym (art. 2 Konstytucji RP) nie ma podstaw do wykorzystywania przez organy podatkowe przepisu art. $70 \$ 6$ pkt 1 o.p. niezgodnie $z$ jego celem (nadużycia prawa). W odniesieniu do organu podatkowego nadużycie prawa przybiera postać przekroczenia kompetencji, gdyż rolą organu jest korzystanie z prawa ${ }^{53}$. Innymi słowy chodzi o nieprzystojne wykorzystywanie kompetencji przez organ podatkowy ${ }^{54}$.

53 Por. A. Łazarska, Rzetelny proces cywilny, Warszawa 2012, s. 574.

${ }_{54}$ Por. E. Łętowska, [w:] Nadużycie prawa, red. H. Izdebski, A. Stępkowski, Warszawa 2003, s. 169. 
Nadużycie prawa przez organ procesowy pociąga za sobą nieporównywalnie większe konsekwencje niż nadużycie praw procesowych przez stronę. Popełnione w ten sposób nadużycie prawa procesowego podważa szacunek wobec porządku prawnego oraz organów władzy ${ }^{55}$. Powyższy standard zachowania organu podatkowego - zgodnie z prawem, a nie wbrew prawu - wynika z zasady praworządności przewidzianej w art. 7 Konstytucji RP, w myśl którego organy władzy publicznej działają na podstawie i w granicach prawa. Z tak sformułowanej normy wywodzone są dwie zasady: zasada praworządności, zgodnie z którą każde działanie powinno być niesprzeczne z jakimkolwiek innym elementem porządku prawnego (w granicach prawa), oraz zasada legalności, zgodnie z którą każde działanie powinno mieć podstawę prawną, czyli stosowną normę rangi ustawowej upoważniającą do konkretnego działania (na podstawie prawa). Legalizm działalności organów administracji publicznej polega m.in. na wydawaniu przez nie rozstrzygnięć w przepisanej prawem formie, na należytej podstawie prawnej i w zgodności z wiążącymi dany organ przepisami materialnymi. Zasada ta dotyczy nie tylko organów publicznych tworzących prawo, ale też stosujących je organów ${ }^{56}$. Artykuł 7 Konstytucji RP ma również samoistne znaczenie, ponieważ jest dyrektywą interpretacji przepisów kompetencyjnych w sposób ścisły i z odrzuceniem w odniesieniu do organów władzy publicznej zasady: co nie jest zakazane, jest dozwolone ${ }^{57}$. Powyższa zasada znajduje odzwierciedlenie w art. 120 o.p., zgodnie z którym organy podatkowe działają na podstawie przepisów prawa. W państwie prawa konieczna jest ocena sposobu korzystania z prawa przez $\operatorname{administrację~}^{58}$. Obowiązek organu podatkowego działania zgodnego z prawem wynika $\mathrm{z}$ prawa do dobrej administracji wywodzonego z zasady demokratycznego państwa prawnego (art. 2 Konstytucji RP), zasady sprawności i rzetelności działań instytucji publicznych (preambuła do Konstytucji RP) czy zasady dobra wspólnego (art. 1 Konstytucji RP). Trybunał Konstytucyjny, przywołując w swoich orzeczeniach prawo do dobrej administracji,

55 Por. S. Waltoś, O obstrukcji procesowej, czyli kilka uwag o nadużyciu prawa procesowego, [w:] W kręgu teorii i praktyki prawa karnego. Księga poświęcona pamięci Profesora Andrzeja Wąska, red. L. Leszczyński, E. Skrętowicz, Z. Hołda, Lublin 2005, s. 620.

${ }_{56}$ Wyrok TK z dnia 12 maja 2015 r., sygn. P 46/13, OTK-A 2015/5/62; por. też J. Lemańska, Uzasadnione oczekiwania w perspektywie prawa krajowego i regulacji europejskich, LEX/el. 2016.

57 Wyrok TK z dnia 27 maja 2002 r., sygn. K 20/01, OTK-A 2002/3/34.

58 Zob. E. Łętowska, Glosa do wyroku NSA z 1 lipca 1999 r., SA/Bk 208/99, OSP 2000, nr 1, poz. 17 . 
w znakomitej większości odwołuje się do źródeł europejskich, wskazując, że prawo do dobrej administracji jest prawem obywatelskim mającym mocne oparcie w postanowieniach art. $41 \mathrm{Karty}^{59}$. Kontrola działania musi zaś być wykonywana przez sąd administracyjny zgodnie ze wskazywaną na wstępie niniejszego artykułu kompetencją w sposób uwzględniający wspomniane zasady.

\section{KONTROLA NADUŻYCIA PRZEZ SĄD ADMINISTRACYJNY} - STANDARD UNIJNY

W przypadku kwestii przedawnienia w sprawach dotyczących VAT mamy do czynienia ze stosowaniem prawa Unii ${ }^{60}$. Oznacza to, że konieczne jest uwzględnienie również standardu unijnego. Wypada przypomnieć, że na gruncie unijnym mamy do czynienia z dwoma równoległymi źródłami praw podstawowych: art. 6 ust. 1 TUE, który odsyła do Karty (art. 47 Karty, art. 17 Karty - prawo własności), oraz art. 6 ust. 3 TUE, który odsyła do praw podstawowych jako ogólnych zasad prawa wynikających z tradycji konstytucyjnych i Europejskiej Konwencji (art. 6 ust. 1 Europejskiej Konwencji, art. 1 Protokołu Dodatkowego Nr 1 do Europejskiej Konwencji ${ }^{11}$ - prawo własności). Pierwsze zasady wynikające z Karty mają „wartość konstytucyjną, a drugie mają po prostu „wartość ogólnych zasad prawa”.

W omawianym przypadku należy zatem brać pod uwagę art. 325 Traktatu o Funkcjonowaniu Unii Europejskiej ${ }^{62}$, art. 2, art. 250 ust. 1 i art. 273 Dyrektywy Rady 2006/112/WE z dnia 28 listopada 2006 r. w sprawie wspólnego systemu podatku od wartości dodanej ${ }^{63}$, art. 4 ust. 3 TUE oraz orzecznictwo TSUE dotyczące terminów przedawnienia i zasady pewności prawa. W myśl art. 325 TFUE państwa członkowskie są zobowiązane do zwalczania nielegalnych działań naruszających interesy finansowe Unii za pomocą odstraszających i skutecznych środków, a w szczególności do stosowania takich samych środków w celu zwalczania przestępczości powodującej naruszenie interesów finansowych Unii, jakie stosują one w celu zwalczania przestępczości powodującej

${ }^{59}$ Wyrok TK z dnia 18 lutego 2003 r., sygn. K 24/02, OTK-A 2003/2/11.

${ }^{60}$ Artykuł 51 ust. 1 Karty; por. też wyrok TSUE z dnia 26 lutego 2013 r., Åkerberg Fransson, C-617/10, EU:C:2013:105.

61 Dz.U. z 1995 r., Nr 36, poz. 175, dalej: Protokół.

${ }^{62}$ Dz.U. z 2004 r., Nr 90, poz. 864/2.

${ }^{63}$ Dz.Urz. UE z dnia 11 grudnia 2006 r., L 347, s. 1, dalej: dyrektywa 112. 
naruszenie ich własnych interesów. Rozważane łącznie w orzecznictwie TSUE art. 2, art. 250 ust. 1 i art. 273 dyrektywy 112 w zw. z art. 4 ust. 3 TUE wskazują na to, że każde państwo członkowskie jest zobowiązane podjąć wszelkie działania ustawodawcze i administracyjne niezbędne do zapewnienia na jego terytorium poboru w pełnej wysokości należnego VAT i zwalczania przestępczości podatkowej ${ }^{64}$. Oznacza to, że o ile państwo członkowskie może wprowadzić pewne przepisy do polskiego porządku prawnego, to jednak obowiązek zapewnienia skutecznego poboru środków Unii nie zwalnia sądów krajowych z konieczności poszanowania praw podstawowych gwarantowanych przez Kartę oraz ogólnych zasad prawa Unii, gdyż postępowania (podatkowe, karne, karne skarbowe) wszczynane w sprawie naruszeń w dziedzinie VAT stanowią stosowanie prawa Unii w rozumieniu art. 51 ust. 1 Karty.

Trybunał Sprawiedliwości nie ma zasadniczych zastrzeżeń co do tego, że państwa członkowskie mogą wprowadzać terminy przedawnienia zobowiązania podatkowego w VAT, albowiem przepisy w tym zakresie nie są zharmonizowane na gruncie prawa unijnego. Państwa członkowskie są jednak zobowiązane do wykonywania tej kompetencji z poszanowaniem prawa Unii i jego ogólnych zasad. Właśnie te terminy mają ogólnie na celu zapewnienie pewności prawa, która chroni jednocześnie podatnika i zainteresowany organ administracji ${ }^{65}$. Zasada pewności prawa obowiązuje wszystkie organy krajowe odpowiedzialne za stosowanie prawa Unii ${ }^{66}$. Powyższy wymóg pewności prawa dotyczy zwłaszcza przepisów podatkowych w celu umożliwienia zainteresowanym dokładnego zapoznania się z zakresem nakładanych przez nie obowiązków ${ }^{67}$. Chodzi o to, aby sytuacja podatnika w zakresie praw i obowiązków podatkowych nie

${ }^{64}$ Zob. wyroki TSUE z dnia: 17 lipca 2008 r., Komisja przeciwko Włochom, C-132/06, EU:C:2008:412, pkt 37, 46; 26 lutego 2013 r., Åkerberg Fransson, C-617/10, EU:C:2013:105, pkt 25.

65 Zob. wyroki TSUE z dnia: 15 lipca 1970 r., ACF Chemiefarma, 41/69, EU:C:1970:71, pkt 19; 24 czerwca 2004 r., Herbert Handlbauer GmbH, C-278/02, EU:C:2004:388, pkt 40; 28 października 2010 r., SGS Belgium i in., C-367/09, EU:C:2010:648, pkt 68; opinia RG J. Kokott z dnia 30 kwietnia 2015 r. do sprawy C-105/14, Ivo Taricco i in., EU:C:2015:293, pkt 87, czy z dnia 14 października 2004 r. w sprawach połączonych Berlusconi i in., C-387/02, C-391/02 i C-403/02, EU:C:2004:624, pkt 107.

66 Zob. wyrok TSUE z dnia 17 lipca 2008 r., ASM Brescia, C-347/06, EU:C:2008:416, pkt 65, i przytoczone tam orzecznictwo.

${ }^{67}$ Por. m.in. wyroki TSUE z dnia: 16 września 2008 r., Isle of Wight Council i in., C-288/07, EU:C:2008:505, pkt 47; 13 grudnia 2012 r., BLV Wohn- und Gewerbebau GmbH, C-395/11, EU:C:2012:799, pkt 47. 
była w nieskończoność narażona na kwestionowanie ${ }^{68}$. Chodzi więc o to, aby nie można było przedłużać w nieskończoność możliwości zakwestionowania sytuacji owego podmiotu pod względem jego praw i obowiązków wobec organu krajowego ${ }^{69}$. Dodatkowo zasada pewności prawa, której konsekwencję stanowi zasada ochrony uzasadnionych oczekiwań, wymaga, po pierwsze, by przepisy prawne były jasne i precyzyjne $e^{70}$, a po drugie, by ich skutki były przewidywalne dla podmiotów prawa, zwłaszcza wówczas, gdy mają one konsekwencje niekorzystne dla jednostek i przedsiębiorstw ${ }^{71}$. Trybunał Sprawiedliwości potwierdził, że pod pewnymi warunkami państwa członkowskie mogą ustanawiać „terminy przedawnienia” dla skorzystania z prawa do odliczenia VAT, o ile nie doprowadzą do zniesienia, faktycznie lub prawnie, tegoż prawa ${ }^{72}$. Pewność prawa, rozumiana w wyrażony wyżej sposób, mogłaby ucierpieć, gdyby wykładnia krajowych przepisów regulujących te terminy była zależna od przypadku lub kaprysu bądź zmieniała się w zależności od poszczególnych organów podatkowych ${ }^{73}$. Oznacza to, że podatnik powinien móc oczekiwać, iż wygaśnięcie zobowiązania podatkowego powinno następować w rozsądnym terminie. Zgodnie z utrwalonym orzecznictwem Trybunału rozsądny charakter terminu nie może być określony poprzez odniesienie do szczególnej górnej granicy, ustalonej w sposób abstrakcyjny. Winien być oceniany na podstawie okoliczności właściwych dla każdej sprawy, takich jak złożoność sporu czy zachowanie właściwych organów i stron, przy czym owa złożoność lub opieszałe zachowanie obrońcy strony mogą uzasadniać zbyt długi na pierwszy rzut oka termin $^{74}$. Konkretne zgodne z prawem Unii stosowanie zasad dotyczących

68 Zob. podobnie wyroki TSUE z dnia: 6 lutego 2014 r., Fatorie, C-424/12, EU:C:2014:50, pkt 46; 9 lipca 2015 r., Cabinet Medical Veterinar Dr. Tomoiagă Andrei, C-144/14, EU:C:2015:452, pkt 39.

${ }^{69}$ Zob. wyrok TSUE z dnia 21 stycznia 2010 r., Alstom Power Hydro, C-472/08, EU:C:2010:32, pkt 16.

70 Wyrok TSUE z dnia 15 lutego 1996 r., Duffi in., C-63/93, EU:C:1996:51, pkt 20.

71 Wyroki TSUE z dnia: 29 kwietnia 2004 r., Sudholz, C-17/01, EU:C:2004:242, pkt 34; 11 czerwca 2015 r., Berlington Hungary i in., C-98/14, EU:C:2015:386, pkt 77.

72 Wyrok TSUE z dnia 9 czerwca 2016 r., Wolfgang und Dr. Wilfried Rey Grundstücksgemeinschaft, C-332/14, EU:C:2016:417, pkt 58-61.

73 Opinia RG MC Sáncheza-Bordony z dnia 26 października 2017 r. do sprawy C-533/16, EU:C:2017:823, pkt 89.

${ }^{74}$ Zob. podobnie wyroki TSUE z dnia: 26 listopada 2013 r., Groupe Gascogne/Komisja, C-58/12 P, EU:C:2013:770, pkt 85, 86; 14 czerwca 2016 r., Marchiani/Parlament, C-566/14 P, EU:C:2016:437, pkt 99, 100. 
okresu i biegu terminów przedawnienia musi wynikać z prawa krajowego. Przy czym autonomia proceduralna państw członkowskich napotyka na dwa ograniczenia: zasadę równoważności i zasadę skuteczności ${ }^{75}$.

Jeżeli zatem sąd krajowy ${ }^{76}$ ma wątpliwości, czy na gruncie prawa krajowego powinien badać kwestię legalności zachowań organu skarbowego w przedmiocie wszczęcia postepowania karnego skarbowego, która ma wpływ na termin przedawnienia poboru zobowiązania w VAT, to już takiej wątpliwości nie powinien mieć na gruncie prawa unijnego, zważywszy w pierwszej kolejności na zasadę pewności prawa i zasadę uzasadnionych oczekiwań. Ponadto TSUE wprost wskazał, że obowiązek zapewnienia skutecznego poboru środków Unii nie zwalnia sądów krajowych z konieczności poszanowania zasady legalności i praworządności, stanowiącej jedną z nadrzędnych wartości, na których opiera się Unia, o czym świadczy art. 2 TUE $^{77}$. Trybunał Sprawiedliwości wskazywał, że akt jest dotknięty wadą nadużycia władzy wówczas, gdy z obiektywnych, właściwych dla danej sprawy i spójnych przesłanek wynika, że został przyjęty wyłącznie lub w znacznej mierze w celu innym niż wskazany albo w celu obejścia procedury przewidzianej w traktacie dla okoliczności danej sprawy ${ }^{78}$. Trybunał podkreślał, że kwestia nadużycia władzy podlega kontroli sądów krajowych $^{79}$. Z taką sytuacją z naruszeniem zasady legalności i praworządności mamy niewątpliwie do czynienia, gdy organ skarbowy, działając jako organ przygotowawczy, wszczyna postępowanie karne skarbowe w celu zawieszenia biegu terminu przedawnienia, a nie w celu rzeczywistego prowadzenia postępowania karnego skarbowego. Oznacza to tym samym naruszenie zasady państwa prawa przewidzianej w art. 2 TUE. Z orzecznictwa TSUE wynika ponadto znaczenie prawa każdej osoby do dobrej administracji. Władze państw członkowskich nie są wprawdzie związane art. 41 Karty, lecz przy wdrażaniu prawa Unii ciąży na nich przewidziany w tymże artykule obowiązek dobrej administracji, ponieważ przepis ten odzwierciedla zasadę

75 Wyrok TSUE z dnia 6 października 2015 r., East Sussex County Council, C-71/14, EU:C:2015:656, pkt 52, i przytoczone tam orzecznictwo.

${ }^{76}$ Choć niektóre składy NSA takiej wątpliwości nie mają, por. wyroki NSA z dnia: 24 listopada 2016 r., sygn. II FSK 1488/15; z 19 kwietnia 2018 r., sygn. II FSK 923/16 i sygn. II FSK 889/16, CBOSA.

77 Wyrok TSUE z dnia 17 stycznia 2019 r., Dzivev, C-310/16, EU:C:2019:30, pkt 35.

78 Wyrok TSUE z dnia 4 grudnia 2013 r., Komisja/Rada, C-117/10, EU:C:2013:786, pkt 96.

79 Por. opinia RG J. Kokott do sprawy C-202/18, EU:C:2018:1030, pkt 57. 
ogólną prawa Unii ${ }^{80}$. Oznacza to, że prawo podmiotowe zagwarantowane w prawie Unii nie może być unieważnione lub wygaszone poprzez zastosowanie terminu przedawnienia, który może być stosowany w sposób niesprawiedliwy lub arbitralny ${ }^{81}$. W relacji Karty do prawa polskiego (w tym Konstytucji RP) standard krajowy musi się mieścić pomiędzy dolną granicą wyznaczoną przez Kartę (powiązaną z minimum Europejskiej Konwencji) a górną granicą wskazywaną przez Trybunał Sprawiedliwości. Konieczność uchylenia standardu krajowego będzie niezbędna, jeżeli występuje zagrożenie dla jednolitości, skuteczności i pierwszeństwa prawa unijnego ${ }^{82}$, choć w tym konkretnym przypadku standardy konstytucyjny i unijny prawa do sądu są równie wysokie. Ten ostatni jest zaś wyraźnie wsparty ogólnymi zasadami prawa (znanymi również polskiej Konstytucji): zasadą państwa prawa, zasadą legalizmu i praworządności oraz zasadą pewności prawa. Argumentem za dokonaniem kontroli sądowej jest też prawo podatnika do dobrej administracji. W przeciwnym razie sąd, odstępując od takiej kontroli, akceptuje stan niepewności sytuacji podatnika co do upływu terminu przedawnienia w zakresie VAT i uzależnienie takiego terminu od uznania organu skarbowego, a w konsekwencji nieuzasadnione ograniczenie prawa własności określonego w treści art. 17 Karty (art. 1 Protokołu).

\section{Charakter KONTROLI NADUŻYCIA PRZEZ SĄD ADMINISTRACYJNY}

Z uzasadnienia wskazywanego na wstępie wyroku NSA nie wynika, aby Sąd rozważał w ogóle istniejące standardy konstytucyjne czy unijne prawa do sądu. W wyroku tym nie rozważano też kwestii naruszenia wspomnianych wyżej zasad mających walor zarówno konstytucyjny, jak i unijny. Fakt, że jak we wspomnianym na wstępie przypadku, sąd uchylił się od kontroli wszczęcia postępowania karnego skarbowego, może wypływać $\mathrm{z}$ jego obawy, że przekroczy on kompetencję w przedmiotowej sprawie. Takie działanie jest o tyle interesujące, iż sądy administracyjne nie mają wątpliwości, że gdy podatnik nadużywa prawa, to pomimo braku wyraźnego zapisu w ustawie okoliczność taka jest brana pod uwagę przez sąd

${ }^{80}$ Wyrok TSUE z dnia 8 maja 2014 r., N., C-604/12, EU:C:2014:302, pkt 49, 50. pkt 39.

81 Opinia RG G. Hogana z dnia 17 stycznia 2019 r. do sprawy C-133/18, EU:C:2019:37,

82 Por. M. Taborowski, Poziom ochrony praw podstawowych wynikajacy z Karty Praw Podstawowych UE jako przeszkoda dla przystapienia Unii Europejskiej do Europejskiej Konwencji Praw Człowieka, EPS 2015, nr 12, s. 31. 
administracyjny. Tutaj jest podobna sytuacja (choć z punktu widzenia państwa prawa, rzekłabym, nie do zaakceptowania, o czym była mowa wyżej), następuje jedynie zmiana strony - prawa nadużywa organ skarbowy, a nie podatnik. Stąd też ocena, że organ skarbowy nadużył prawa, wszczynając postępowanie karne skarbowe w celu innym aniżeli cel tego postępowania, tj. wyłącznie po to, aby zawiesić bieg terminu przedawnienia zobowiązania podatkowego, nie będzie powodować wzruszenia czynności na gruncie prawa karnego skarbowego. Ocena ta będzie miała tylko walor wstępny dla określenia konsekwencji opisanego działania na gruncie podatkowym. Sam przecież ustawodawca skonstruował warunek zawieszenia biegu terminu przedawnienia w taki sposób, że otworzył możliwość weryfikacji warunku dla potrzeb podatkowych. Postępowanie sądu administracyjnego można sprowadzić do prostego testu nadużycia. Wystarczy zadać lapidarne pytanie, czy w sytuacji, gdyby nie istniał art. $70 \$ 6$ pkt 1 o.p., organy skarbowe dokonałyby wszczęcia postępowania karnego skarbowego. Odpowiedź negatywna świadczy o nadużyciu prawa przez organ skarbowy. Rezultat takiej kontroli uzależniony jest zatem od okoliczności każdej konkretnej sprawy. Stwierdzenie tego rodzaju nadużycia prawa powinno skutkować na gruncie sprawy podatkowej odmową rozpoznania wskazanego wyżej skutku. Innymi słowy działanie kwalifikowane jako nadużycie prawa nie może wywołać skutku korzystnego dla działającego. Stąd też finalnym skutkiem najczęściej będzie stwierdzenie upływu terminu przedawnienia ${ }^{83}$, o ile nie zajdą inne przesłanki przerwania lub zawieszenia terminu.

Taki przypadek zachodzi wówczas, gdy organy skarbowe tuż po wszczęciu postępowania karnego skarbowego nie podejmują żadnych działań w celu m.in. wykrycia sprawcy, zbierania dowodów ${ }^{84}$, a więc nie realizują celów tego postępowania. Organ przygotowawczy, wszczynając postępowanie karne skarbowe (w fazie ad rem), nie może później nic nie robić, zwłaszcza w ramach procedury, w której nie uczestniczy podatnik, a od której uzależniony jest upływ terminu przedawnienia. Działania powinny zmierzać do prawomocnego zakończenia postępowania w sprawie o przestępstwo skarbowe lub wykroczenie skarbowe. Warto też wskazać, że zadaniem Krajowej Administracji Skarbowej jest m.in. rozpoznawanie, wykrywanie i zwalczanie przestępstw skarbowych i wykroczeń skarbowych,

83 Por. uchwały składu 7 sędziów NSA z dnia: 28 kwietnia 2014 r., sygn. I FPS 8/13; 26 lutego 2018 r., sygn. I FPS 5/17, CBOSA.

84 Por. art. $297 \$ 1$ Ustawy z dnia 6 czerwca 1997 r. Kodeks postępowania karnego (Dz.U. z 2018 r., poz. 1987) w zw. z art. $113 \$ 1$ Kodeksu karnego skarbowego. 
zapobieganie tym przestępstwom i wykroczeniom oraz ściganie ich sprawców $^{85}$. Zadaniem Administracji Skarbowej (jej organów) nie jest bezzasadne wszczynanie postępowań karnych skarbowych i ich dalsze nieprowadzenie. Podobny skutek ma wszczęcie postępowania karnego skarbowego w sytuacji nieumyślności działania podatnika na skutek istnienia ugruntowanej linii orzeczniczej ${ }^{86}$ czy upływu terminu przedawnienia karalności ${ }^{87}$.

\section{Podsumowanie}

Z powyższej argumentacji wynika, że sąd administracyjny nie może odstąpić od kontroli działań organów skarbowych noszących znamiona nadużycia prawa, szczególnie w sprawach dotyczących VAT, będących sprawami z zakresu stosowania prawa Unii. Ustawodawca, włączając pewne konstrukcje karne skarbowe do Ordynacji podatkowej, zdecydował o tym, że stały się one elementem instytucji prawa podatkowego, jaką jest instytucja przedawnienia. I jak każdy element tej instytucji, podlega on badaniu sądu administracyjnego. Rezygnacja zaś z tej kompetencji doprowadzi do sytuacji, w której upływ terminu przedawnienia będzie zależeć od uznania organu podatkowego i będzie poza jakąkolwiek kontrolą sądową. Takie działanie stoi w sprzeczności z rolą sądów administracyjnych, jaką jest wymierzanie sprawiedliwości oraz z konstytucyjnym i unijnym prawem do sądu. Sąd nie może być obojętny na patologiczne zachowania administracji. Obojętność po stronie sądów może doprowadzić do bezkarności organów skarbowych. Działania organów skarbowych noszące znamiona nadużycia prawa godzą zaś w zasadę państwa prawa, w którym organy władzy publicznej powinny działać zgodnie z zasadą legalności i praworządności, a także w prawo do dobrej administracji. Nie można również zapominać w takiej sytuacji o naruszeniu zasady pewności prawa, albowiem podatnicy mają prawo oczekiwać od państwa, że upływ terminu przedawnienia nie będzie miał waloru pozornego i uzależnionego od uznania organu skarbowego. Skutkiem takiego działania organów skarbowych będzie ograniczenie wykonywania prawa własności w sposób nieproporcjonalny i trudny do zaakceptowania, co stanowi naruszenie art. 17 Karty w zw. z art. 52

${ }^{85}$ Artykuł 2 ust. 1 pkt 13 Ustawy z dnia 16 listopada 2016 r. o Krajowej Administracji Skarbowej (Dz.U. z 2016 r., poz. 1947 ze zm.).

${ }^{86}$ Por. wyrok Wojewódzkiego Sądu Administracyjnego we Wrocławiu z dnia 22 lipca 2019 r., sygn. I SA/Wr 365/19, CBOSA.

${ }^{87}$ Wyrok NSA z dnia 24 listopada 2016 r., sygn. II FSK 1488/15, CBOSA. 
ust. 1 Karty (art. 1 Protokołu) oraz art. 21 ust. 1 i art. 64 Konstytucji RP w zw. z art. 31 ust. 3 Konstytucji RP.

Należy wyraźnie podkreślić, że rolą sądu administracyjnego jest rzeczywiste przeciwdziałanie nadużyciu prawa, zwłaszcza gdy dokonywane jest przez organ władzy. Jak powiedział Arystoteles w Etyce nikomachejskiej $(\mathrm{V}, 10,1137 \mathrm{~b})$, zapobiegać tego typu wypadkom dysfunkcjonalności prawa pozytywnego można jedynie dzięki odwołaniu się do norm o jeszcze bardziej ogólnym charakterze, które zawierają nadzwyczajne umocowanie dla sądu, by ten, kierując się bardzo ogólnie określonym standardem etycznym, postrzeganym jednak w kontekście aksjologii całego systemu prawnego, rozstrzygnął konkretną kwestię sporną w sposób sprawiedliwy. Takimi normami w omawianym przypadku są normy konstytucyjne i unijne. Warto wspomnieć tutaj znaną paremię łacińską - nemo potest commodum capere de iniuria sua propria (nikt nie może czerpać korzyści z własnego bezprawia). Tym bardziej bezprawia nie może się dopuszczać organ skarbowy, którego obowiązkiem jest działanie zgodnie z literą prawa. Akceptacja przez sąd administracyjny popełnionego przez organy skarbowe nadużycia prawa nie tylko pogłębia brak zaufania podatników do tychże organów ${ }^{88}$, lecz także rodzi brak zaufania do takiego sądu w sytuacji, gdy nie chroni on obywatela przed samowolą i niezgodnym z prawem działaniem władzy ${ }^{89}$.

\section{BibLIOgRAFiA}

Arystoteles, Etyka nikomachejska, przeł. D. Gromska, Warszawa 2012.

Dauter B., Kabat A., Niezgódka-Medek M., Prawo o postępowaniu przed sądami administracyjnymi. Komentarz, wyd. 7, LEX/el. 2018.

Gajewska-Kraczkowska H., O prawdziwej funkcji zawieszenia postępowania karnego skarbowego, „Monitor Podatkowy” 2012, nr 4.

Garlicki L., Polskie prawo konstytucyjne. Zarys wykładu, Warszawa 2012.

Gomułowicz A., Podatki i etyka, Warszawa 2013.

Konstytucja Rzeczypospolitej Polskiej. Komentarz, red. M. Haczkowska, LEX/el. 2014.

Konstytucja Rzeczypospolitej Polskiej. Komentarz, t. 2, red. L. Garlicki, M. Zubik, wyd. 2, LEX/el. 2016.

Lemańska J., Uzasadnione oczekiwania w perspektywie prawa krajowego i regulacji europejskich, LEX/el. 2016.

Łabuda G., Zawieszenie postępowania karnego skarbowego ze względu na prejudykat, „Prokuratura i Prawo" 2011, nr 3.

${ }^{88}$ Artykuł $121 \$ 1$ o.p.

89 Por. A. Gomułowicz, Podatki i etyka, Warszawa 2013, s. 184-185. 
Łazarska A., Rzetelny proces cywilny, Warszawa 2012.

Łętowska E., [w:] Nadużycie prawa, red. H. Izdebski, A. Stępkowski, Warszawa 2003.

Łętowska E., Glosa do wyroku NSA z 1 lipca 1999 r., SA/Bk 208/99, OSP 2000, nr 1, poz. 17.

Nieczepa O., Poinformowanie podatnika o wszczęciu postępowania karnoskarbowego jako moment skutecznego zawieszenia biegu terminu przedawnienia zobowiązania podatkowego po upływie 5-letniego terminu przedawnienia. Glosa do wyroku NSA $z$ dnia 16 stycznia 2013 r., I FSK 1208/11, „Glosa” 2015, nr 3.

Pozycja ustrojowa sędziego, red. R. Piotrowski, LEX/el. 2015.

Szyburska-Walczak G., Oddziaływanie europejskiej Konwencji o ochronie praw człowieka $i$ podstawowych wolności na internacjonalizację standardów w dziedzinie demokracji i praw człowieka, [w:] Wpływ standardów międzynarodowych na rozwój demokracji i ochrone praw człowieka, red. J. Jaskiernia, Warszawa 2013.

Taborowski M., Poziom ochrony praw podstawowych wynikajacy z Karty Praw Podstawowych UE jako przeszkoda dla przystąpienia Unii Europejskiej do Europejskiej Konwencji Praw Człowieka, EPS 2015, nr 12.

Trzciński J., Sądownictwo administracyjne jako gwarant ochrony wolności i praw jednostki, [w:] Trzecia władza. Sądy i trybunały w Polsce, red. A. Szmyt, Gdańsk 2008.

Tychmańska A., Znaczenie Międzynarodowego Paktu Praw Obywatelskich i Politycznych oraz Międzynarodowego Paktu Praw Gospodarczych, Społecznych i Kulturalnych dla polskiego porządku prawnego na przykładzie analizy orzecznictwa polskich sądów administracyjnych, „Studenckie Zeszyty Naukowe” 2017, t. 22, nr 34.

Waltoś S., O obstrukcji procesowej, czyli kilka uwag o nadużyciu prawa procesowego, [w:] W kręgu teorii i praktyki prawa karnego. Księga poświęcona pamięci Profesora Andrzeja Wąska, red. L. Leszczyński, E. Skrętowicz, Z. Hołda, Lublin 2005.

Wieruszewski R., Oddziaływanie prawa międzynarodowego i prawa Unii Europejskiej na konstytucyjny status jednostki w RP, [w:] Otwarcie Konstytucji RP na prawo międzynarodowe i procesy integracyjne, red. K. Wójtowicz, Warszawa 2006.

\section{CAN THE ADMINISTRATIVE COURT REFRAIN FROM REVIEW THE ABUSE OF RIGHTS COMMITTED BY TAX AUTHORITIES? COMMENTS REGARDING the judgment of the Supreme Administrative Court of November 24, 2016 (I FSK 759/15)}

Summary. The author of the article points to the erroneous practice of administrative courts, according to which they do not examine the initiation of criminal fiscal proceedings by tax authorities in order to merely suspend the limitation period pursuant to art. $70 \$ 6$ item 1 of the Tax Ordinance Act (abuse of rights). Such action is incompatible with the constitutional and EU right to court, as well as the rule of law and the principles derived from them: legality, legal certainty and the right to good administration. Consequently, the abandonment of such judicial review leads to a violation of the taxpayer's property right.

Keywords: suspension of the statute of limitation on a tax liability, criminal and fiscal proceedings, right to a fair trial 